UNITED STATES

DEPARTMENT OF THE INTERIOR

GEOLOGICAL SURVEY

PRELIMINARY STUDY OF QUATERNARY FAULTING

ON THE EAST SIDE OF BARE MOUNTAIN, NYE COUNTY, NEVADA

By

MARITH C. REHEIS

Open-File Report 86-576

Prepared in cooperation with the

Nevada Operations Office

U.S. Department of Energy

(Interagency Agreement DE-AI08-78ET44802)

This report is preliminary and has not been reviewed for conformity with U.S. Geological Survey editorial standards and stratigraphic nomenclature. Any use of trade names is for descriptive purposes only and does not imply endorsement by the USGS. Denver, Colorado
1986 


\section{CONTENTS}

Page

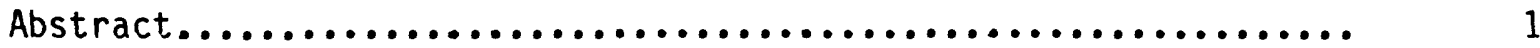

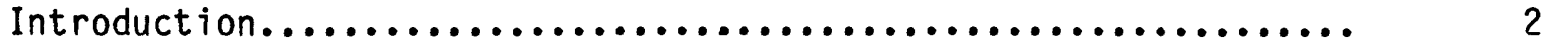

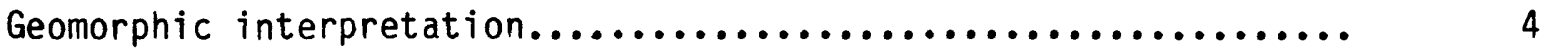

Field reconnaissance.....................................

- Faults in older Pleistocene and Tertiary units.............

Faults in younger Pleistocene and Holocene units............. 7

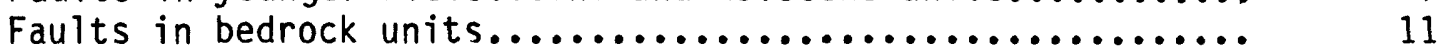

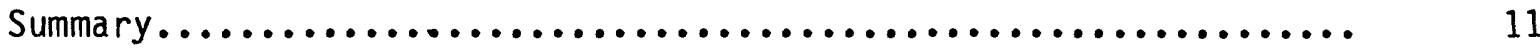

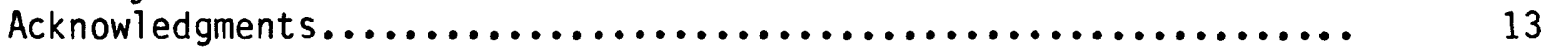

References......................................... 14

\section{ILLUSTRATIONS}

Figure 1.--Map of Quaternary faulting on the east side of

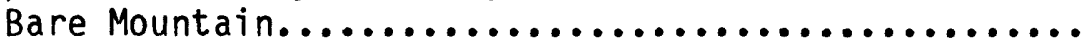

2.--Photographs of (a) secondary $\mathrm{CaCO}_{3}$ cementing zone along fault cutting younger Pleistocene side of Tarantula Canyon at site 1.

(b) slickensides on secondary silica in fault exposed in p. uspect pit north of Chuckwalla

Canyon at site 2............................

3.--Photographs of (a) north-facing prospect pit exposing fault in probable early Holocene fan overlying Paleozoic limestone at site 3.

(b) closeup of disturbed zone and shingling of clasts at angles up to $65^{\circ} \ldots \ldots \ldots . .$.

4.--Photographs of (a) north wall of prospect pit at site 4. (b) fractures in buried soil...........

5.--Photograph of north wall of prospect pit at

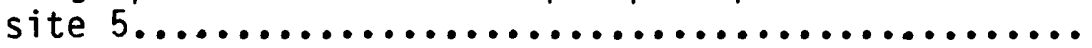




\title{
PRELIMINARY STUDY OF QUATERNARY FAULTING \\ ON THE EAST SIDE OF BARE MOUNTAIN, NYE COUNTY, NEVADA
}

By

\section{Marith C. Reheis}

\begin{abstract}
Active faults bound the east side of Bare Mountain. Geomorphic features, stratigraphy, and soil development indicate that two 3-km-long segments of the range-front fault probably last moved in Holocene or late Pleistocene time. Other segments of the fault have been quiescent since the late Pleistocene. Both late Pleistocene and Holocene deposits bury many faults east of the northern end of Bare Mountain.
\end{abstract}

Two prospect pits on the range-front fault reveal evidence of recurrent late Quaternary movements. Both older and younger deposits in one pit are faulted, but fractures in the older unit do not extend up into the younger unit. Based on soil development, the older and younger fault episodes respectively are probably late Pleistocene and Holocene in age. Another pit shows carbonate-cemented fractures with slickensides in a late Pleistocene deposit, suggesting at least two late Pleistocene or Holocene fault movements.

Middle to early Pleistocene and Tertiary deposits show evidence of recurrent faulting in many locations. Faults in these deposits are pervaded by secondary $\mathrm{CaCO}_{3}$ and silica that commonly exhibit slickensides. 


\section{INTRODUCTION}

The eastern range front of Bare Mountain trends northward and lies about $15 \mathrm{~km}$ west of the proposed nuclear waste disposal site at Yucca Mountain (fig. 1). Bare Mountain consists of complexly faulted Paleozoic rocks intruded by Tertiary rhyodacitic dikes (Cornwall and Kleinhampl, 1961). The range front is structurally controlled by a system of normal faults that have remained active during Quaternary time (Swadley and others, 1984; Carr, 1984). Several small earthquakes (less than magnitude 3) from 1978 to 1984 had epicenters located along the range-front fault (Rogers and others, 1983; Carr, 1984). However, previous workers have mapped few faults in the fan alluvium that fringes the mountain front, except in the area east of the northern end of Bare Mountain.

Preliminary interpretation of mapping, soil studies, and aerial photographs indicate that the Bare Mountain range-front fault cuts deposits of Pleistocene and probable Holocene age in numerous places. Evidence for recurrent activity on this fault in mid-Pleistocene to Holocene time is found in several localities.

The ages of Quaternary deposits are estimated using soil development and surface characteristics (Hoover and others, 1981). The Harden index of soil development (Harden, 1982; Harden and Taylor, 1983) is used to quantify soil properties in order to compare the ages of soils in different areas. Soils were compared to those developed in similar climates on dater alluvial deposits in Fortymile Wash, $25 \mathrm{~km}$ east of Bare Mountain (fig. 1; Taylor, 1985) and in Kyle Canyon, $115 \mathrm{~km}$ to the southwest (Sowers, 1985). Although the Fortymile Wash area is closer, the Kyle Canyon soils formed on carbonate-rich deposits similar to those at Bare Mountain. Soils on the calcareous Kyle Canyon and Bare Mountain fans with similar characteristics, such as thickness of the $\mathrm{A}$ and $\mathrm{B}$ horizons and stage of pedogenic $\mathrm{CaCO}_{3}$ and silica accumulation, should be of comparable age.

In general, the terms Holocene, younger Pleistocene, and older Pleistocene in this report correspond to the Q1, Q2, and QTa units of Hoover and others (1981). However, age assignments of these deposits in Swadley and others (1984) along the Bare Mountain range front may be too old. For example, the latter workers used petrocalcic horizons to identify units 0.2c and QTa, believed to be older than $250 \mathrm{ka}$. Units with similar development were originally dated with the uranium-trend method in relatively noncalcareous alluvium on the Nevada Test Site (Hoover and others, 1981). Many of the Bare Mountain alluvial fans are mainly composed of carbonate sediments in which pedogenic $\mathrm{CaCO}_{3}$ probably forms much more rapidly than in areas of other provenance. Petrocalcic horizons are found in similar soils dated with uranium-thorium methods at $120 \mathrm{ka}$ (Sowers, 1985) on calcareous fans in kyle Canyon. Thus, soils formed in calcareous alluvium are prohably younger than soils with comparable amounts of $\mathrm{CaCO}_{3}$ formed in non-calcareous alluvium. 

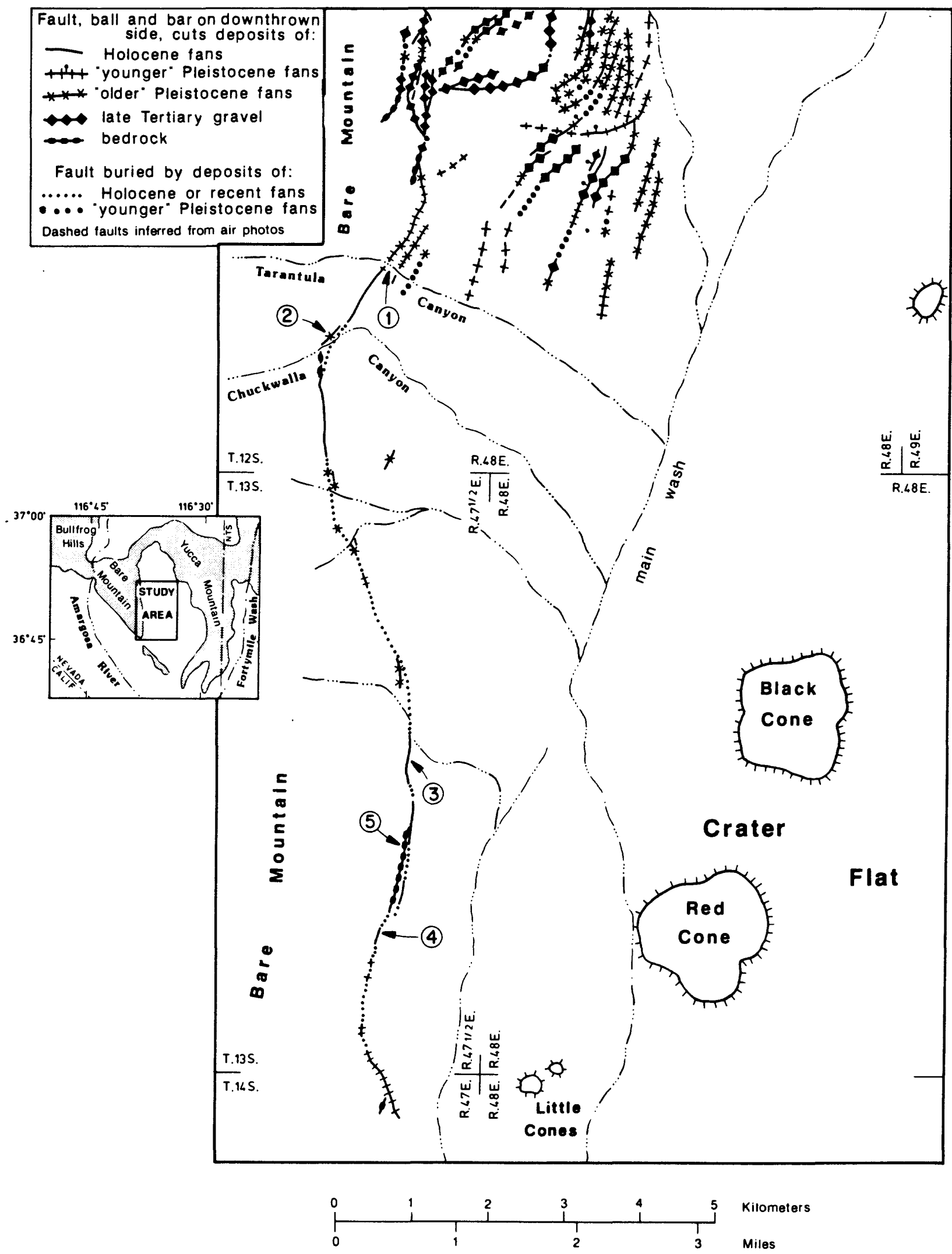

Figure 1.--Map of Quaternary faulting on the east side of Bare Mountain. Faults with no bar and ball are down to the south or east. Circled numbers refer to sites discussed in the text and other figures. Hachured lines delimit Quaternary cinder cones. Inset map shows the relation of the study area to regional geographic features. 


\section{GEOMORPHIC INTERPRETATION}

Geomorphic characteristics of the Bare Mountain-Crater Flat area indicate recurrent Quaternary faulting (fig. 1, and map of Swadley and others, 1984). The Bare Mountain front is steep with faceted spurs. Drainages are deeply incised within the mountains, but are aggrading on the surface of steeplysloping Holocene alluvial fans that bury older fans adjacent to the mountain front south of Tarantula Canyon. This relation suggests that recent uplift along the range front has caused drainages to deposit young alluvium over older alluvium (Bull, 1964). Holocene deposits north of Tarantula Canyon are mainly confined to arroyos cut into older deposits, which suggests that faulting there has not been as recent. This unequal distribution of Holocene fans along the Bare Mountain front indicates a local tectonic control of stream gradients rather than a regional climatic control.

Geomorphic features on aerial photographs (air photos, scale $1: 12,000$ ) also indicate probable Quaternary faults. Linear features such as brush lines and disturbed ground (extensive areas of rodent burrows) commonly mark the traces of faults that offset Quaternary alluvium in the area of the Nevada Test Site. Such features are abundant in Holocene and Pleistocene deposits along the range-front fault, and in Pleistocene deposits north of the Tarantula Canyon drainage. Only two obvious scarps along the range front are recognized in air photos. One scarp is on the south side of Tarantula Canyon (site 1, fig. 1), and the other, now destroyed by recent mining activity, is about $1.5 \mathrm{~km}$ south of the boundary between townships 12 and 13 (fig. 1). Both scarps offset fans which appear to be of middle to late Pleistocene age. Many small drainages appear to be offset along the range-front fault as they debouch onto the piedmont slope. Whether the drainages are following weaknesses caused by recent faulting or the bedrock is not known. As a result of these active channels at the bedrock-alluvium contact, exposures of the range-front fault are rare.

\section{FIELD RECONNAISSANCE}

The faults on Figure 1 were mapped both on the bas is of exposures in arroyos and prospect pits and air photo interpretation. Arroyos cutting older Pleistocene deposits commonly expose steeply dipping fault zones with secondary calcium carbonate $\left(\mathrm{CaCO}_{3}\right)$ and amorphous silica. These zones correspond to linear features in air photos (sites 1 and 2). Because faults in young deposits are not cemented with $\mathrm{CaCO}_{3}$ or silica, they are more difficult to discern. Linear zones of disturbed ground and abrupt changes in the gradients of fan surfaces are believed to indicate faults in younger deposits. Three prospect pits (sites 3,4 and 5) expose faults in late Pleistocene or Holocene deposits. Some fault segments along the range front pass from alluvium into bedrock (site 5 ).

Most of the range-front faults dip between $60^{\circ}$ to $80^{\circ}$ eastward. An exception is the $35^{\circ}-45^{\circ}$ southeastward-dipping segment of the range-front fault that strikes northeast from Chuckwalla Canyon (fig. 1). This segment projects into a shallowly dipping normal fault in bedrock that continues to the head of Chuckwalla Canyon (Cornwall and Kleinhampl, 1961; M. D. Carr, oral commun., 1985). 
Offset is difficult to determine on most of the faults because of poor exposures and the uniformity of the alluvial fan deposits. Assuming that the faults are normal, as are many local faults in bedrock, most of the offsets are down to the east or south. Antithetic faults seem to be present at sites 1 and 4 (fig. 1), but exposures are poor and excavations are needed to determine their nature and extent.

\section{Faults in 01der Pleistocene and Tertiary Units}

Arroyo walls and prospect pits expose faults in older alluvial fans along linear features noted on air photos. Faults are most abundant in the area north of Chuckwalla Canyon drainage (fig. 1). The fault zones are typically 0.25-1 $\mathrm{m}$ wide (fig. $2 \mathrm{a}$ ). The zones are always cemented with secondary $\mathrm{CaCO}_{3}$ and sometimes amorphous silica, which apparently precipitate from groundwater or from rainwater and surface runoff percolating through the fault zones. A fault zone is commonly accompanied by several thinner, carbonate-cemented fractures within $30 \mathrm{~m}$ of the main zone. These fractures show no offset but are probably fault-related, as they occur only in areas that are faulted.

Clasts within the fault zones are usually oriented with their long axes parallel to the boundaries of the cemented zone. Presumably the clasts were oriented by drag along the fault, although near-vertical orientations can also result when clasts fall into open surface fractures caused by faulting ( $K$. $L$. Pierce, oral commun., 1985; and Crone and others, 1985), or into animal burrows. The latter two mechanisms usually result in a wide range of clast orientations, however, rather than one preferential orientation.

Multiple offsets have occurred on a number of the faults in older units. The $\mathrm{CaCO}_{3}$ and silica cement within the fault zones, emplaced after one or more fault movements, commonly exhibits slickensides that indicate the fault moved after at least some of the cementation occurred (fig. $2 b$ ). The slickensides on exposures of the range-front fault are usually perpendicular to the local trend of the mountain front.

Accurate ages of the faults in older alluvial units are not known. Some of the faults cut older Pleistocene fans and/or Tertiary gravel but are buried by younger Pleistocene and Holocene alluvium (fig. 1); these faults are therefore probably mid-Pleistocene in age or older. Other faults cut both older and younger Pleistocene units, but are buried by Holocene alluvium; these may be late Pleistocene in age. Extensive $\mathrm{CaCO}_{3}$ cementation along a fault zone probably indicates that at least one movement of the fault occurred in late Pleistocene time or earlier, for the cementation process is slow. Faults in late Pleistocene and Holocene deposits are not cemented, although secondary $\mathrm{CaCO}_{3}$ does occur locally along young faults.

One radiometric date was obtained by the uranium-series method for a cemented fault zone (site 2, fig. 1) along Bare Mountain (B. J. Szabo, oral commun., 1985). The age of secondary silica with slickensides (fig. $2 \mathrm{~b}$ ) is $>350 \mathrm{ka}$. Thus, the fault movement that permitted cementation to begin probably predates $350 \mathrm{ka}$, but the age of the movement that produced the slickensides is known only to be younger than the initiation of cementation. 
a

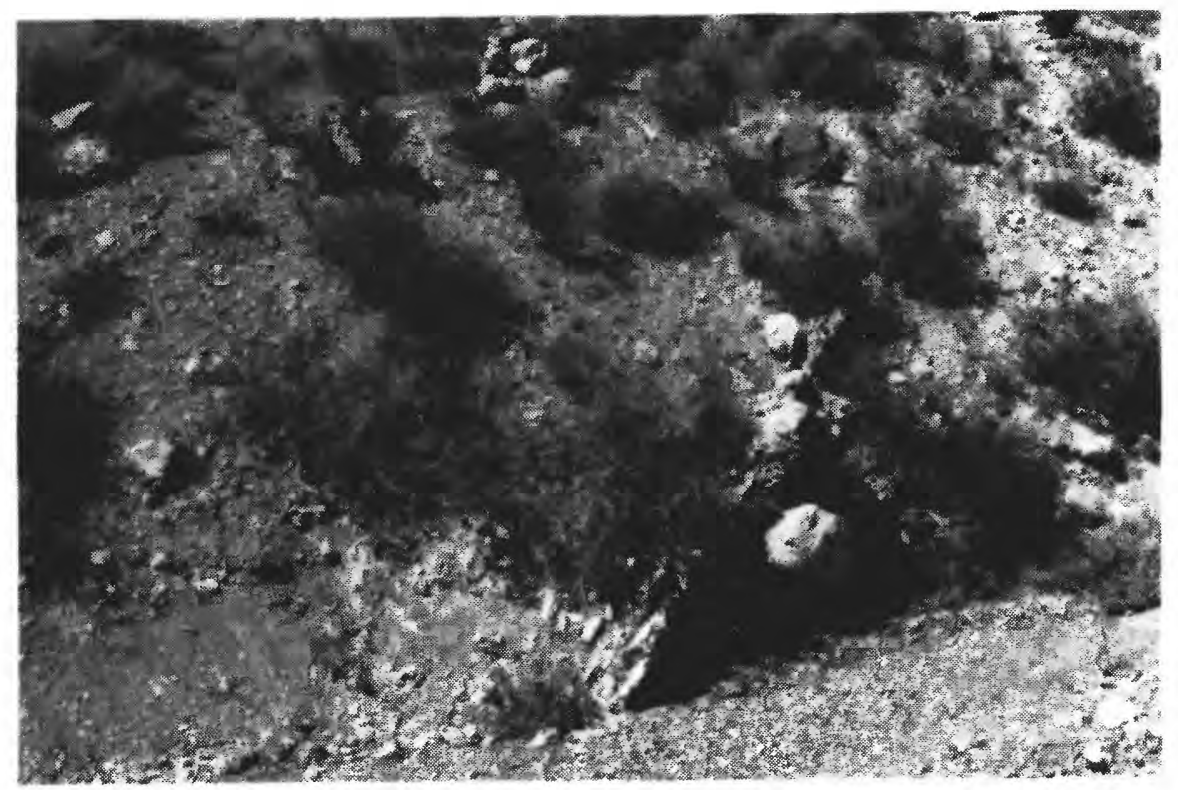

b

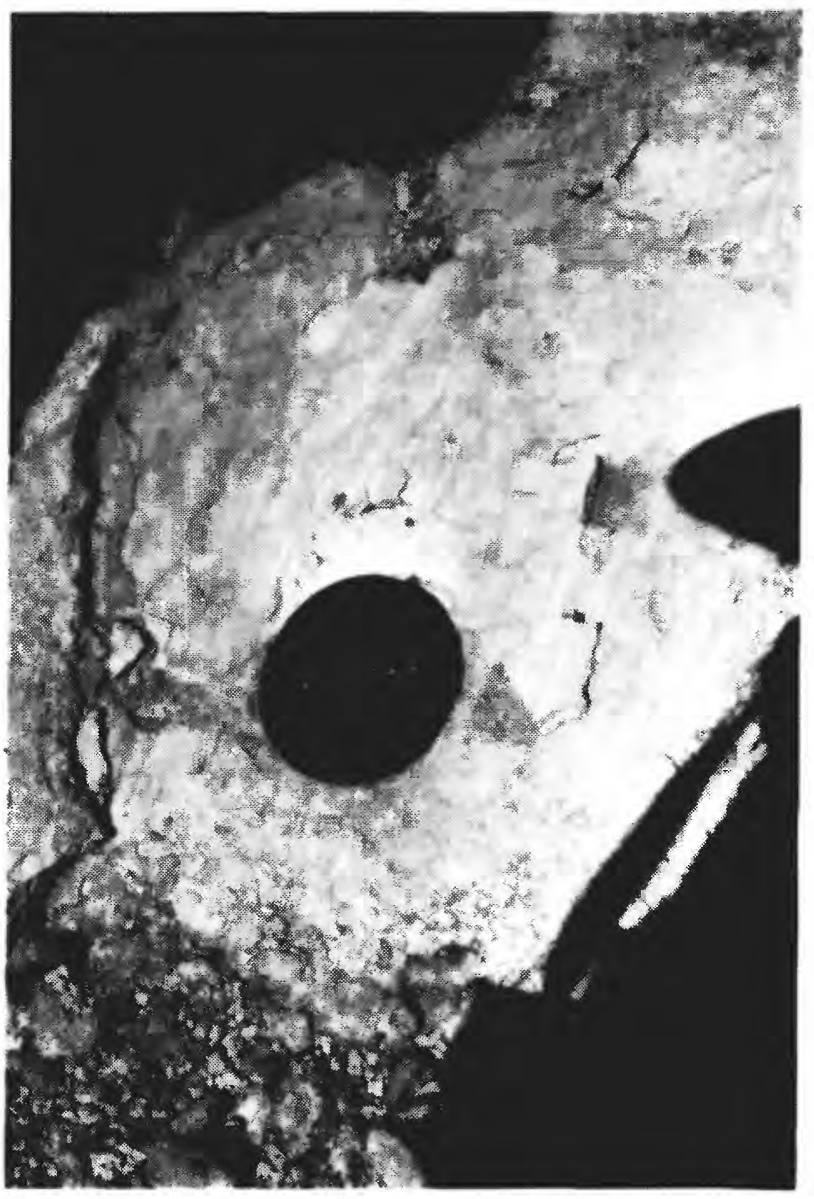

Figure 2.--(a) Secondary $\mathrm{CaCO}_{3}$ cementing zone along fault cutting younger Pleistocene alluvium on south side of Tarantula Canyon at site 1 . Fault zone is marked by hammer on top of large white boulder. (b) Slickensides on secondary silica in fault exposed in prospect pit north of chuckwalla Canyon at site 2. The silica is dated at $>350 \mathrm{ka}$ (B. J. Szabo, oral commun., 1985). 


\section{Faults in Younger Pleistocene and Holocene Units}

In general, subsurface exposures of faults in young alluvial units are poor because they are unconsolidated, so a fault origin for many of the linear features on the surface of these units in the air photos is equivocal. Brush lines in these units may be caused by the plants rooting through thin, young deposits into fault zones in underlying older deposits. In spite of these difficulties, two prospect pits (sites 3 and 4 , fig. 1 ) reveal good evidence of late Pleistocene or Holocene movement on the Bare Mountain range-front fault, and two other pits (site 5) provide supporting evidence for recent faulting.

A prospect pit exposes a small alluvial fan deposited against faulted Paleozoic limestone (site 3 , fig. 1). A probable fault cuts the alluvium parallel to and about one meter east of the bedrock outcrop (fig. 3a), where a gravelly bed of alluvium adjacent to the bedrock stops at the fault and appears to be cut by it. Clasts in the deposit are oriented parallel to the fan surface slope except along the fault zone, where the clasts are parallel to the fault (fig. 3b). The area of the presumed fault has animal burrows, but the clasts in this area have fairly uniform orientation; clasts that fell into burrows would probably have more randomly distributed orientations.

The surface morphology and the soil developed on this fan suggest that the fan and the subsequent faulting are probably Holocene in age and no older than late Pleistocene. The surface is bouldery and has little or no desert pavement. These characteristics are typical of Holocene and late Pleistocene surfaces in the area (Hoover and others, 1981). The soil has a weak, sandy, vesicular A horizon, 2-3 cm thick, and a slightly oxidized, calcareous $B$ horizon. $\mathrm{CaCO}_{3}$ development consists of coats up to $1 \mathrm{~mm}$ thick on clast bottoms. These properties are typical of soils developed on deposits believed to be early Holocene and late Pleistocene in age in Fortymile Wash (Taylor, 1985), and soils on a 5- to 15-ka fan in Kyle Canyon.

Evidence of two successive movements of the range-front fault is exposed in an excavation at site 4 (fig. 1). The north wall of this pit (fig. 4a) exposes gravelly sediment in fault contact with Paleozoic limestone. The fault plane strikes $\mathrm{N} 35^{\circ} \mathrm{E}$ and dips $58^{\circ} \mathrm{SE}$. Clasts as large as boulders are oriented parallel to the fault plane, in a zone about $50 \mathrm{~cm}$ wide along the bedrock surface. Most of the clasts away from this zone are oriented parallel to the ground surface or are randomly oriented. Two Quaternary deposits are recognized in the excavation. The younger deposit disconformably overlies a buried soil formed in the older deposit. Both deposits are very poorly sorted and stratified, and in many places clast-supported with very little fine matrix. These deposits may have accumulated at the base of a free face formed by faulting (Wallace, 1977).

The buried soil contains numerous vertical fractures (fig. 4b) and has two fractures that parallel the main fault plane (fig. 4a). The eastern of these two fractures is lined by secondary $\mathrm{CaCO}_{3}$ (fig. $4 \mathrm{~b}$ ), but shows no evidence of offset. Movement may have occurred on the western fracture, because some large clasts have been rotated parallel to it (fig. 4a). All of the fractures terminate upward at the top of the buried soil. This soil is well-preserved and may have been rapidly buried, perhaps in part by colluvium shed from the fault scarp. 

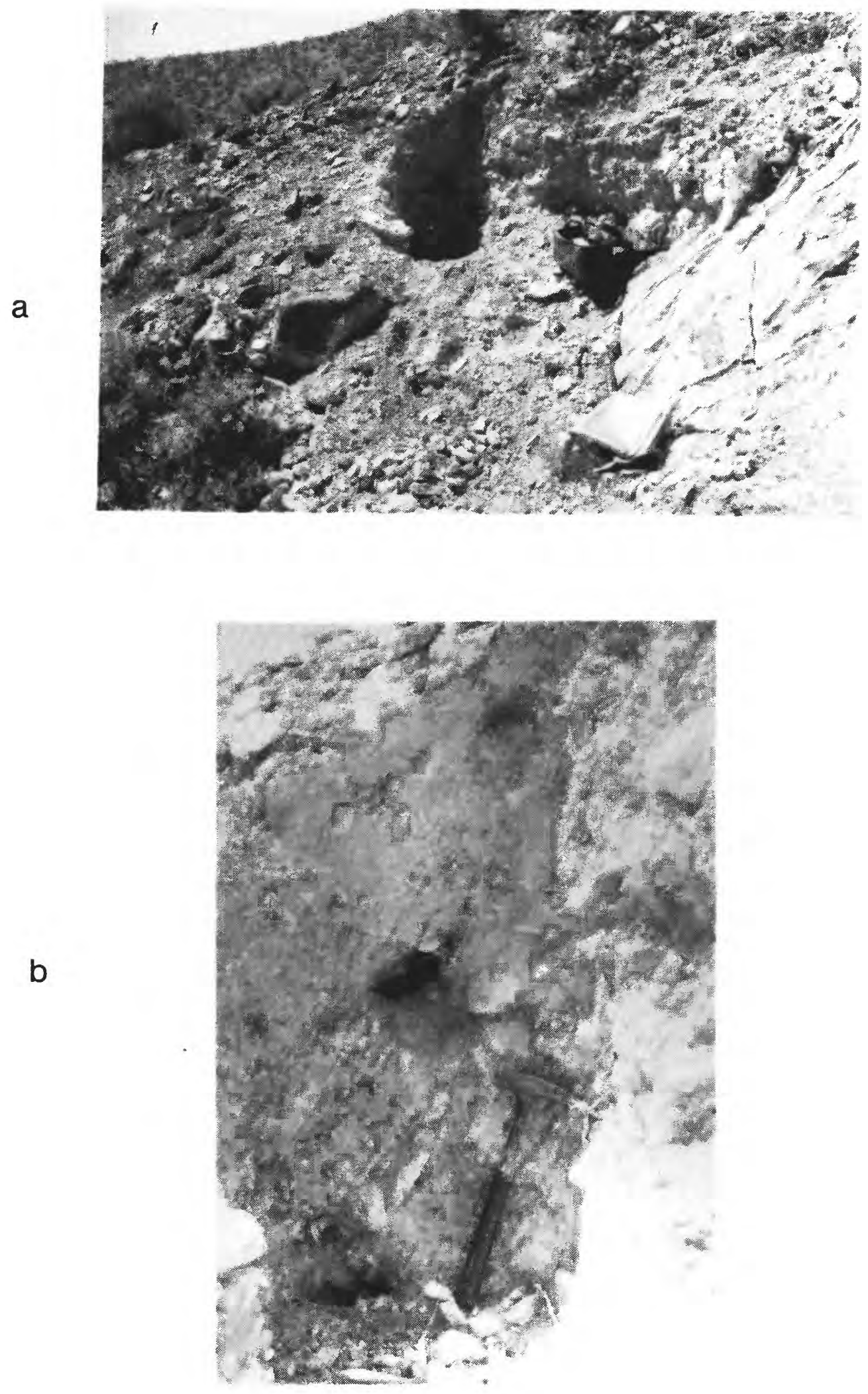

Figure 3.--(a) North-facing prospect pit exposing fault in probable early Holocene fan overlying Paleozoic 1imestone at site 3. Gravelly alluvium adjacent to bedrock is cut by fault. Fan surface slopes east at $25^{\circ}$. (b) Closeup of disturbed zone and shingling of clasts at angles up to $65^{\circ}$. 
The older deposit is probably mid-Pleistocene in age, based on soil morphology. This buried soil has remnants of an A horizon overlying welldeveloped structure in the $\mathrm{B}$ horizon. Pedogenic $\mathrm{CaCO}_{3}$ and silica coat clast. bottoms and occur in the finer matrix between clasts, but do not cement the soil horizons. The $\mathrm{CaCO}_{3}$ and silica morphology is similar to that of soils formed on late to middle Pleistocene deposits (Q2b) in Fortymile Wash that are believed to be 145-160 ka (Swadley and others, 1984). Typical values of the Harden profile index for soils on Q2b deposits range from 28 to 44 (Taylor, 1985); the profile index value calculated for the buried soil is 39 . These values are probably comparable because this particular deposit contains relatively high proportions of quartzite rather than carbonate gravel, in contrast to most of the Bare Mountain alluvium. Thus, the parent material for the soils in this prospect pit resembles the carbonate-poor alluvium of uranium-trend-dated soils on the Nevada Test Site more closely than the carbonate-rich alluvium of soils at Kyle Canyon.

The episode of faulting that fractured the buried soil must have occurren after most of the soil properties were developed, but before the deposition of the overlying material. The buried fractures are very clear and wellpreserved. Had the fractures formed before most of the soil properties, the fractures would have been disrupted and destroyed by processes such as bioturbation during subsequent soil formation.

The younger deposit has definitely been faulted. Clasts near the main fault plane parallel the bedrock (fig. $4 a$ ). These clasts must have heen oriented within the younger alluvium, for the dip angle is too steep to he maintained as a free face. At the contact between the younger deposit and the buried soil is a laminar $\mathrm{CaCO}_{3}$ layer $1-2 \mathrm{~cm}$ thick (fig. $4 \mathrm{~b}$ ). This layer is continuous across the exposure but stops at the zone of oriented clasts near the fault plane. Pieces of laminar $\mathrm{CaCO}_{3}$ oriented parallel to the fault plane occur within this zone about $1.75 \mathrm{~m}$ above the continuous laminar layer (fig. 4a). The laminar layer resembles those found in petrocalcic soil horizons. However, it is unlikely to have formed as part of the buried soil because the layer overlies the $B$ horizon of this soil; such layers normally occur within or below B horizons of well-drained soils. The laminar layer probably formed after the younger deposit buried the older one, hecause the buried soil, being compact and weakly cemented, acted as a permeability barrier to percolating, $\mathrm{CaCO}_{3}$-saturated water. If the oriented pieces of laminar $\mathrm{CaCO}_{3}$ were derived from the laminar layer, they indicate that the fault moved at least $1.75 \mathrm{~m}$ vertically after deposition of the younger unit and formation of the laminar layer at its base. The exposed limestone bedrock has a degraded scarp of comparable height.

The morphology of the surface soil formed on the younger deposit suggests that this deposit and the fault movement that affected it are Holocene in age. Pedogenic $\mathrm{CaCO}_{3}$ and silica occur only as coats on clast bottoms; the $A$ horizon is sandy, and the B horizon is weakly oxidized. These characteristics are similar to those of Holocene soils in Kyle Canyon. The Harden index value of the surface soil is 20, which corresponds to values for soils on early Holocene deposits (unit Q1c, believed to be about $9 \mathrm{ka}$ ) in Fortymile Wash (Taylor, 1985). 

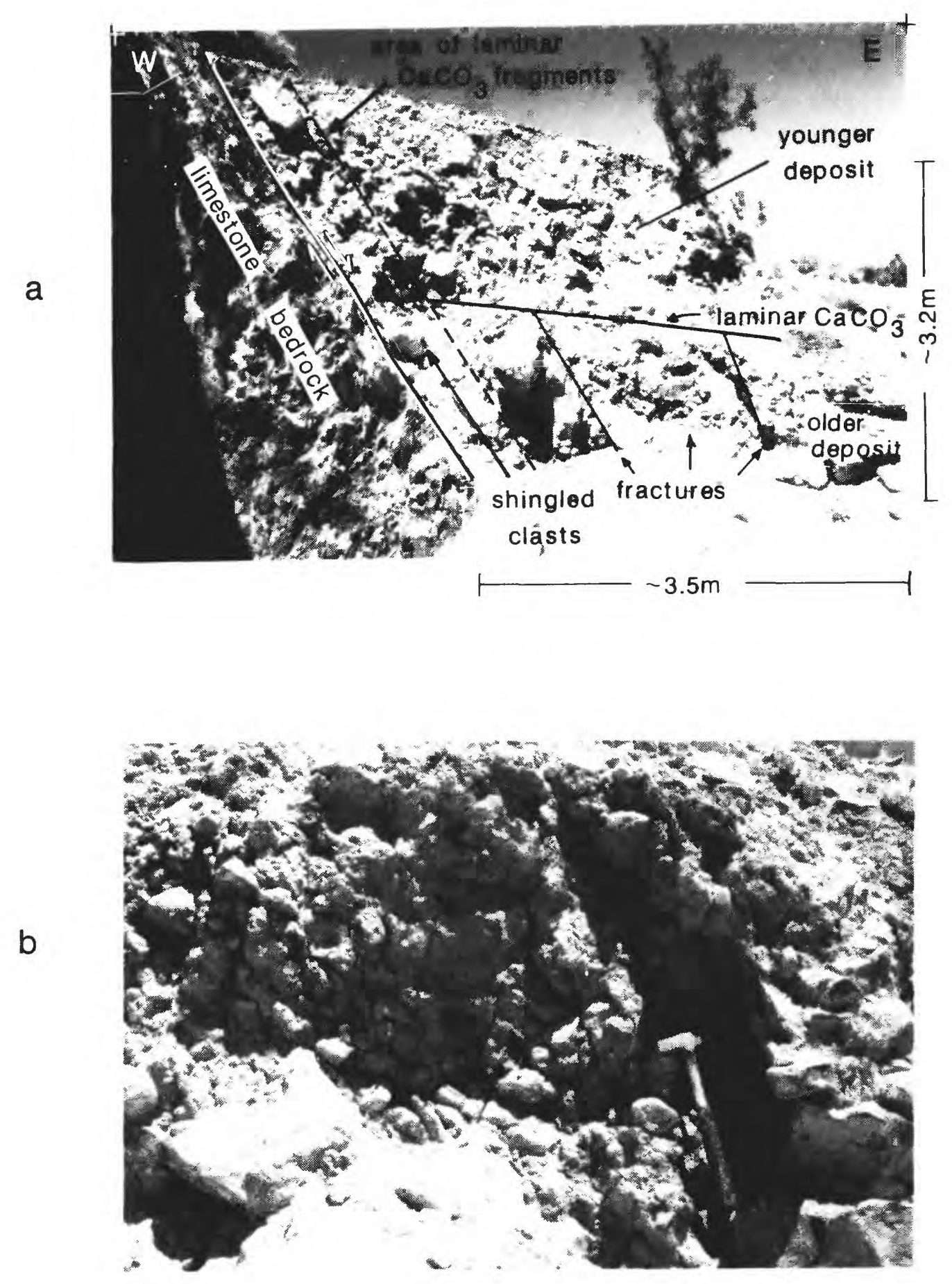

Figure 4.--(a) North wall of prospect pit at site 4. Faulted early Holocene to late Pleistocene deposit overlies buried soil on faulted middle Pleistocene(?) deposit. (b) Fractures in buried soil. Laminar layer visible at top of photograph. Secondary $\mathrm{CaCO}_{3}$ outlines fracture to right of hammer. 


\section{Faults in Bedrock Units}

Bedrock may have been offset during Holocene or late Pleistocene time at site 5 (fig. 1) on a splay of the range-front fault. In one prospect pit (fig. 5), a Tertiary dike emplaced in Paleozoic limestone is sheared and brecciated, and has slickensides along its contact with the limestone at the base of the exposure. Near the ground surface, the limestone and dike rocks are separated by about $1 \mathrm{~m}$ of colluvium with vertically oriented clasts. Some of these clasts are petrocalcic fragments; secondary $\mathrm{CaCO}_{3}$ occurs on the tops and sides of other clasts reworked from older soils. This wedge may represent material that fell into an open fracture formed by fault movement along the limestone-dike contact; similar wedges were observed in fractures along recent faults caused by the Borah Peak earthquake (K. L. Pierce, oral commun., 1985; Crone and others, 1985). The soil formed on the colluvial wedge has a thin, sandy A horizon, a weakly oxidized $\mathrm{B}$ horizon, and little pedogenic $\mathrm{CaCO}_{3}$, suggesting that the colluvium was deposited in early Holocene time.

A second prospect pit at site 5 exposes the dike in contact with a younger Pleistocene deposit. The soil on this deposit is similar in $\mathrm{CaCO}_{3}$ development to the buried soil at site 4 , but has less pedogenic silica; the soil at site 5 is similar to soils formed on 40-50 ka deposits in Fortymile Wash (unit Q2a, Taylor, 1985). The deposit in the prospect pit contains a near-vertical zone of secondary $\mathrm{CaCO}_{3}$ that is separated from but parallels the alluvium-dike contact, and slickensides occur on the plates of $\mathrm{CaCO}_{3}$. These relations suggest that two movements of the fault occurred here after deposition of the alluvium.

\section{SUMMARY}

The Bare Mountain range-front fault and the associated northern fault complex have been active in Quaternary time. Relations in prospect pits and linear features on air photos suggest that Holocene or late Pleistocene faulting has occurred along two segments (fig. 1): 1) from site 4 to $1 \mathrm{~km}$ north of site 3 ; and 2) from about $2 \mathrm{~km}$ south of Chuckwalla Canyon to Tarantula Canyon. Between the two segments and south of site 4 , the rangefront fault probably last moved in middle to late Pleistocene time.

Recurrent movement has occurred on the range-front fault and the northern fault complex. Two episodes of faulting have occurred since the late Pleistocene at site 4 (fig. 4), and are indicated at site 5 (fig. 5). Recurrent faulting is also demonstrated at numerous locations by slickensides preserved on secondary $\mathrm{CaCO}_{3}$ and silica in fault zones (fig. 2).

Early Pleistocene (?) and Tertiary deposits are complexly faulted north of the Tarantula Canyon drainage (fig. 1), but none of the faults appear to extend upward into Holocene deposits, and few mid to late Pleistocene (?) fans are faulted. These relations suggest that this area is relatively inactive. The fault complex appears to stop near the Tarantula Canyon drainage, but this may be due to burial by younger Pleistocene fans that extend from this drainage south. 


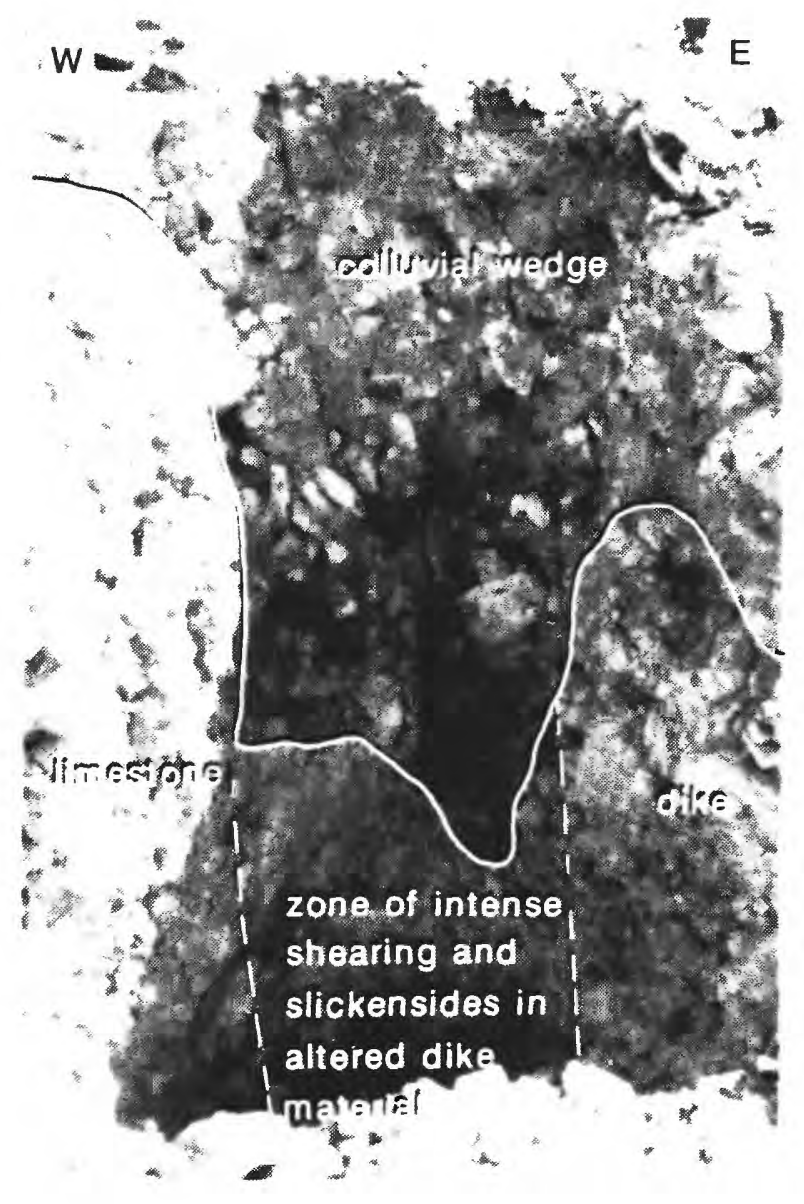

Figure 5.--North wall of prospect pit at site 5. Faulted limestone-dike contact with probable Holocene colluvial wedge filling formerly open fracture. 
The north-northeast trend of the northern fault complex roughly parallels the line of Pleistocene cinder cones in Crater Flat (fig. 1). In addition, the two active segments of the range-front fault trend north or northnortheast, as do long drainage segments in Crater Flat. This local trend is similar to a regional trend of recent tectonic features noted by Carr (1984), and suggests structural control of the Crater Flat drainages.

\section{ACKNOWLEDGMENTS}

- This work was performed in cooperation with the U.S. Department of Energy, Nevada Nuclear Waste Storage Investigations Project. M. D. Carr, $D$. V. Prose, and K. K. Harms read and commented on early versions of this manuscript. Discussions with WC Swadley, J. W. Whitney and E. M. Taylor gave useful perspectives. G. Vick provided able field assistance, and C. C. Reheis provided entertainment. 


\section{REFERENCES}

Bul1, W. B., 1964, Geomorphology of segmented alluvial fans in western Fresno County, California: U.S. Geological Survey Professional Paper 352-E, p. $89-129$.

Carr, W. J., 1984, Regional structural setting of Yucca Mountain, southwestern Nevada, and late Cenozoic rates of tectonic activity in part of the southwestern Great Basin, Nevada and California: U.S. Geological Survey - Open-File Report 84-854, 109 p.

Cornwall, H. R., and Kleinhampl, F. J., 1961, Geology of the Bare Mountain quadrangle, Nevada: U.S. Geological Survey Geologic Quadrangle Map GO157, scale $1: 62,500$.

Crone, A. J., Pierce, K. L., and Hait, M. H. Jr., 1985, The Borah Peak earthquake of October 28, 1983: Surface faulting, mass movements, and Quaternary tectonic setting of the Lost River Range: Reological Society of America Field Trip Guide, 1985 Rocky Mountain Section Meeting, Boise, Idaho, $44 \mathrm{p}$.

Harden, 1982, A quantitative index of soil development from field descriptions: Examples from a chronosequence in central California: Geoderma, v. 28, p. 1-28.

Harden, J. W., and Taylor, E. M., 1983, A quantitative comparison of soil development in four climatic regimes: Quaternary Research, v. 20, p. 342359.

Hoover, D. L., Swadley, W C, and Gordon, A. J., 1981, Correlation characteristics of surficial deposits with a description of surficial stratigraphy in the Nevada Test Site region: U.S. Geological Survey OpenFile Report 81-512, 27 p.

Rogers, A. M., Harmsen, S. C., Carr, W. J., and Spence, W., 1983, Southern Great Basin seismological data report for 1981 and preliminary data analysis: U.S. Geological Survey Open-File Report 83-669, 240 p.

Sowers, J. M., 1985, Pedogenic calcretes of the Kyle Canyon alluvial fan, southern Nevada: Morphology and development: Ph. . . thesis, University of California at Berkeley, Berkeley, Cal ifornia, $159 \mathrm{p}$.

Swadley, W C, Hoover, D. L., and Rosholt, J. N., 1984, Preliminary report on late Cenozoic faulting and stratigraphy in the vicinity of Yucca Mountain, Nye County, Nevada: U.S. Geological Survey Open-File Report 84-788, 42 p., scale 1:62,500.

Taylor, E. M., 1985, Paleoclimatic interpretations of the geomorphology and Quaternary soils in the Yucca Mountain area of the Nevada Test Site: M.S. thesis, University of Colorado, Boulder, Colorado.

Wallace, R. E., 1977, Profiles and ages of young fault scarps, north-central Nevada: Geological Society of America Bulletin, v. 88, p. 1267-1281. 